\title{
Productivity enhancement and popularization of improved production technologies in wheat through frontline demonstrations
}

\author{
Vivek Sharma, Vijay Kumar*, S.C. Sharma and Sukhvinder Singh \\ Regional Research Station for Kandi Area (Punjab Agricultural University), Ballowal Saunkhri, Teh. Balachaur, \\ SBS Nagar- 144521 (Punjab), INDIA \\ *Corresponding author. E-mail: vijaypau@pau.edu \\ Received: July 22, 2015; Revised received: December 7, 2015; Accepted: March 15, 2016
}

\begin{abstract}
Front line demonstrations (FLDs) on wheat were conducted on 150 farmers' fields to demonstrate the impact of drought tolerant rainfed varieties (PBW 175 \& PBW 644) and other improved practices techniques (supplemental irrigation and sowing with seed drill) on production and economic benefits in the kandi region of Punjab state during rabi seasons from 2011-12 to 2013-14 under rainfed situation. The improved production technologies recorded additional mean yield of $27.8 \mathrm{q} / \mathrm{ha}$ and $28.4 \mathrm{q} / \mathrm{ha}$ for rainfed varieties and other improved practices. The per cent average increase in yield of rainfed over local cultivars was 35.3, while 29.1 for other improved practices. The average extension gap, technology gap and technology index were $7.3 \mathrm{q} / \mathrm{ha}, 8.4 \mathrm{q} / \mathrm{ha}$ and 22.5 per cent, respectively in different varieties. FLDs recorded higher B:C ratio of 2.32 and 2.52 for rainfed varieties and other improved practices, respectively. The FLDs conducted on improved technologies during the present study resulted in enhancement of yield, net returns and also increased the knowledge of the farmers. Thus, productivity of wheat could be increased by adopting recommended improved management practices with a suitable high yielding variety under rainfed conditions. The present study resulted in convincing the farming community about potentialities of improved production management technologies of wheat in productivity enhancement and for further adoption by the farming community.
\end{abstract}

Keywords: FLDs, Rainfed, Supplemental irrigation, Seed drill, Wheat

\section{INTRODUCTION}

Wheat (Triticum aestivum) is the second most important winter cereal in India after rice contributing substantially to the national food security by providing more than $50 \%$ of the calories to the people who mainly depend on it. During 2013, globally it was cultivated on an area of $219 \mathrm{~m}$ ha with production of $715.9 \mathrm{~m}$ tonnes. In India, wheat is the second most important food crops after rice being cultivated on $29.6 \mathrm{~m}$ ha with production of $93.5 \mathrm{mt}$ with an average productivity of $31.5 \mathrm{q} / \mathrm{ha}$ (FAO, 2013). In Punjab it is grown on $3.5 \mathrm{~m}$ ha area with production $16.6 \mathrm{~m}$ ton and productivity of $47.3 \mathrm{q} /$ ha (Anonymous, 2013). The sub-mountainous region in the North-Eastern part of Punjab (NBSSLUP agro-ecological sub-region 9.1) in the form of a 10 to $20 \mathrm{~km}$ wide strip immediately next to Shiwalik hills is known as 'Kandi'. The area of kandi region is approx. 3.93 lakh hectares which comprises approximately 7.8 per cent of total geographical area of the State. This zone is located between $30^{\circ} 44^{\prime}$ and $32^{0} 32^{\prime} \mathrm{N}$ latitude and $75^{\circ} 52^{\prime}$ and $76^{\circ} 43^{\prime} \mathrm{E}$ longitude at an elevation of 300-500 $\mathrm{m}$ above mean sea level. The productivity of wheat is much lower as compared to average state productivity in this region due to cultivation of the crop under rainfed conditions as well as poor knowledge about drought tolerant varieties and production practices are ascribed as main reasons for low productivity. However, in the past decade a general slowdown in increase in the productivity of wheat has been noticed, particularly under environments relatively unfavorable for growth and development of wheat (Nagarajan, 2005). The main reason of low productivity is low availability of irrigation water for the proper growth and development, especially on critical stages of growth. (Joshi et al., 2007).During past few years, more than $50 \%$ sowing of wheat gets delayed till December or early January causing substantial loss in grain yield due to late harvesting of preceding kharif crop like rice, which ultimate results in poor seed yield due to unavailability of sufficient irrigation water. Moreover, poor agronomic practice such as seed rate, selection of suitable variety, nutrient management, weed management and irrigation management etc. are responsible for low productivity of wheat in India (Tiwari et al., 2014). Frontline demonstration is the new concept of field demonstration evolved by the Indian Council of Agriculture Research (ICAR) with main objective to demonstrate newly released crop production and protection technologies and its management practices in the farmers' fields under different agro-climatic regions of the country under 
different farming situations. While demonstrating the technologies in the farmer's fields, the scientists are required to study the factors contributing higher crop production, field constraints of production and thereby generate production data and feedback information. Keeping this in view, frontline demonstrations (on farmer's fields) on wheat were conducted to demonstrate the production potential and economic benefits of drought tolerant varieties and latest improved technologies and convincing the farmers to adopt the improved production technologies of wheat for enhancing the productivity of wheat in the region.

\section{MATERIALS AND METHODS}

Total of 150 frontline demonstrations (FLDs) to demonstrate the effect of high yielding rainfed varieties, supplemental irrigation (crown root initiation stage (CRI) and CRI + flowering stage) and sowing with seed drill on the productivity of wheat were conducted during rabi season from 2011-12 to 2013- 2014 on farmers' fields under rainfed conditions in villages such as NaudeMajra, Rajgiri, Jhandian, Jatawar, Dhamana (Distt. Rupnagar), Achalpur and Nainwan (District Hoshiarpur) of Punjab. The soils of the farmer fields were light to medium with low to medium fertility status. Each demonstration was conducted on an area of 0.2 ha and adjacent plot $(0.1 \mathrm{ha})$ to the demonstration plot was kept for assigning farmers practices. Before conducting FLDs, a list of farmers was prepared from group meeting and specific skill training was given to the selected farmers regarding package of practices of wheat.

To popularize the improved wheat production practices, constraints in wheat production were identified though participatory approach. Preferential ranking technique was utilized to identify the constraints faced by the respondent farmers in wheat production. Farmers were also asked to rank the constraints they perceive as limiting factor for wheat cultivation in order of preference. Based on top rank farmers problems identified, front line demonstrations were planned and conducted at the farmer's fields. The improved technologies selected for FLDs were improved high yielding rainfed varieties, supplemental irrigation and drill sowing. The other management practices like seed treatment, recommended fertilizers dose and plant protection etc. were applied for improved as well as farmer practice. The spacing followed was at $22.5 \mathrm{~cm}$ (row-row) sown between last week of October to second week of November during the three years with the seed rate of $100 \mathrm{~kg} / \mathrm{ha}$. The data for number of tillers per plant, number of plants per meter, grain yield, straw yield, harvest index, production and economic data was recorded, compared with farmer practice and analyzed. The average of the individual improved/ local practice for the three years has been taken for interpretation of the results.

The extension gap, technology gap and technology index were calculated using the formula as suggested by Samui et al. (2000).

Extension gap $(\mathrm{q} / \mathrm{ha})=$ Demonstration yield $(\mathrm{q} / \mathrm{ha})$ Yield of local check $(\mathrm{q} / \mathrm{ha})$.

Technology gap $(\mathrm{q} / \mathrm{ha})=$ Potential yield $(\mathrm{q} / \mathrm{ha})$ Demonstration yield $(\mathrm{q} / \mathrm{ha})$.

Technology index $(\%)=\{($ Potential yield - Demonstration yield) / Potential yield $\}$ x 100

Knowledge level of the farmers about improved production practices of wheat before frontline demonstration implementation and after implementation was measured and compared by applying paired t-test at 5 per cent level of significance.

\section{RESULTS AND DISCUSSION}

Constraints in wheat production: Problems faced by the farmer's in wheat cultivation were documented during the study. Preferential ranking technique was utilized to identify the constraints faced by the respondent farmers in wheat production and rankings given by the farmers to different constraints are given in Table 1. A perusal of table indicated that non-availability of rainfed varieties seed $(75 \%)$ was given the top most rank followed by damage by wild and stray animals $(70 \%)$, uncertainty of rains $(68 \%)$, low technical knowledge $(65 \%)$ and yellow rust disease of wheat were the major constraints to wheat cultivation. Other constraints such as weed infestation and low soil fertility were also found to reduce wheat production. Ranawat et al. (2011), Dhruw et al. (2012) and Meena et al. (2014) have also reported similar type of constraints such as lack of suitable varieties; low technical knowledge etc. in maize production and the results of the present study also indicated similar constraints in wheat production.

\section{Performance of FLD}

Yield attributing traits (Rainfed varieties): The average number of plants per square metre and number of tiller per plant in wheat under improved practice were 57 and 6 , which was 27.0 and 50.0 per cent higher over the farmers practice (Table 2). The grain yield and straw yield of wheat under improved technology ranged from 25.5 to 30.0 and 38.3 to $41.4 \mathrm{q} /$ ha with average values of 27.8 and $39.9 \mathrm{q} / \mathrm{ha}$, respectively. The average harvest index of wheat under improved technology (0.41) also showed increase of 9.4 per cent over the farmer's practice (0.38). The low yield of

Table 1. Ranks given by farmers for different constraints $(\mathrm{n}=100)$.

\begin{tabular}{llcc}
\hline S & Constraints percentage & Percentage & Rank \\
N. & ranks & 75 & I \\
\hline 1 & Rainfed Varieties seed & 60 & V \\
2 & Yellow rust & 30 & VII \\
3 & Low soil fertility & 65 & IV \\
4 & Low technical knowledge & 70 & II \\
5 & Damage by wild animals & 68 & III \\
6 & Uncertainty ofrains & 33 & VI \\
7 & Weed infestation & & \\
\hline
\end{tabular}


Vivek Sharma et al. / J. Appl. \& Nat. Sci. 8 (1): 423 - 428 (2016)
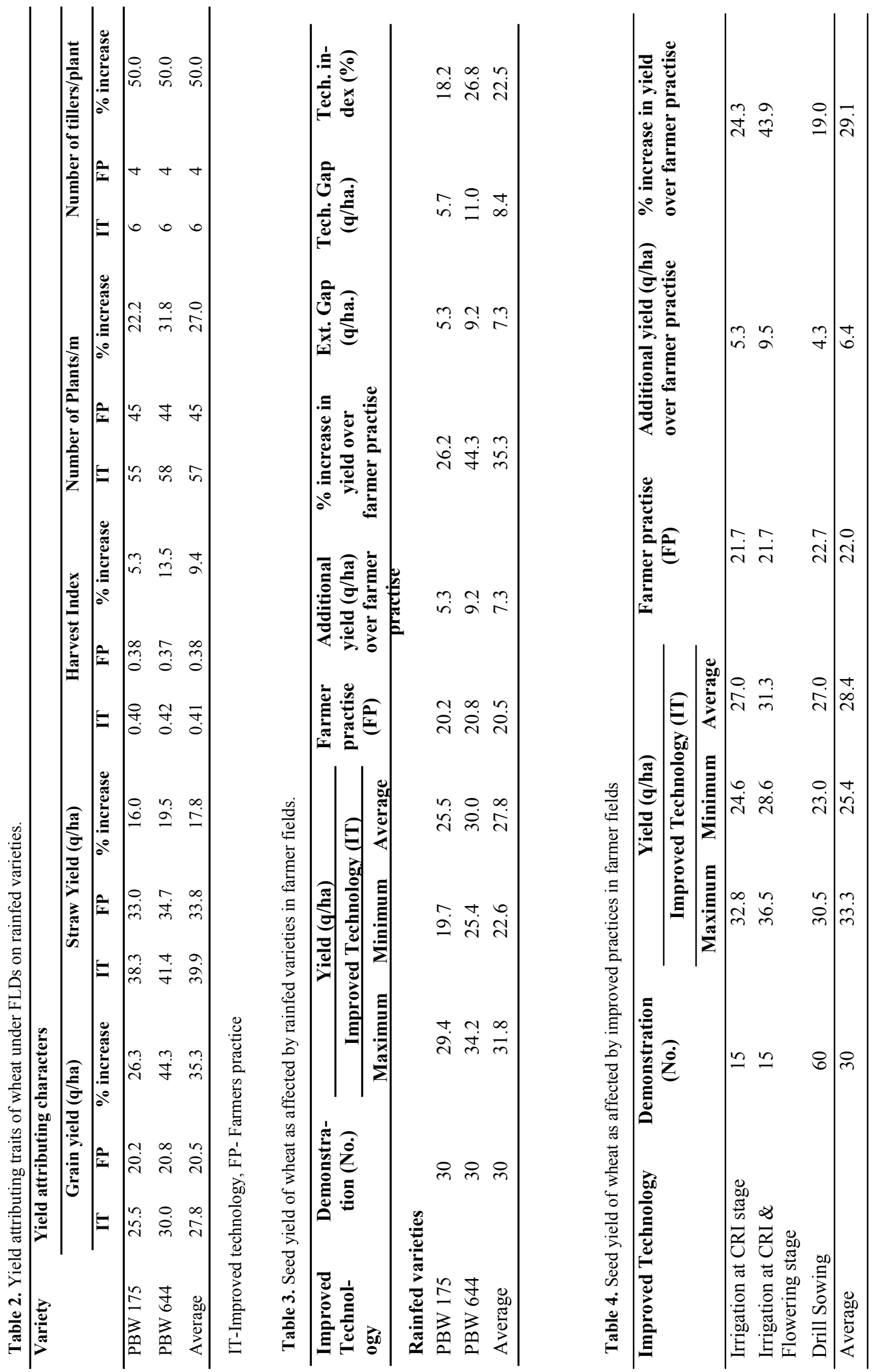
wheat in farmers' field might be due to the use of local / unknown cultivars due to non-availability of the quality rainfed seed.

\section{Production}

Rainfed varieties: The productivity with rainfed varieties varied from 19.7 to $29.4 \mathrm{q} / \mathrm{ha}$ and 25.4 to $34.2 \mathrm{q} / \mathrm{ha}$ with average yield of $25.5 \mathrm{q} / \mathrm{ha}$ and $30.0 \mathrm{q} / \mathrm{ha}$ for the varieties PBW 175 and PBW 644, respectively against the average yield $20.5 \mathrm{q} / \mathrm{ha}$ of local cultivar even under improved management practices (Table 3 ). The additional yield of different high yielding varieties ranged 5.3 to $9.2 \mathrm{q} / \mathrm{ha}$ with a mean of $7.3 \mathrm{q} / \mathrm{ha}$ in comparison to local varieties. The per cent increase in yield of rainfed varieties over local cultivars ranged from 26.2 to 44.3 with an average of 35.3 per cent.

The yield of FLDs and potential yield of the different varieties of crop was compared to estimate the yield gaps and technology index. The value of extension gap varied from 5.3 to $9.2 \mathrm{q} /$ ha with an average value of $7.3 \mathrm{q} / \mathrm{ha}$. The findings revealed that a gap exists between the actual farmer's yield and realizable yield potential of the variety. Hence, to exploit the potential of improved production and protection technologies efforts through FLDs ought to be increased awareness among the farmers (Singh et al., 1995). The extension gap during the study period emphasizes the need to educate the farmers through various means for adoption of improved agricultural production technologies to reverse the trend. The technology gap shows the gap in the demonstration yield over potential yield and the average value was $8.4 \mathrm{q} / \mathrm{ha}$. The observed technology gap may be due dissimilarity in the soil fertility status, weather condition and other management practices (Mitra et al., 2010; Katare et al., 2011 and Tiwari et al., 2014). Hence variety-wise location specific recommendation with full package of practices and other pre-requisite appears to be necessary to minimize the technology gap for yield level under different situations. Such steps would boost up the production and bring more prosperity to the farming community. Technology index $(22.5 \%)$ showed the feasibility of the variety at the farmer's field. The lower the value of technology index more is the feasibility. The wider gap in technology index (ranging between 18.2-6.8\%) during the study period in certain region, may be attributed to the difference in soil fertility status, weather conditions, non availability of irrigation water and insect-pests attack in the crop (Singh et al., 1995).

Supplementary irrigations and use of seed drill in wheat: The productivity of wheat (Table 4) in the FLDs with the help of supplementary irrigations and use of seed drill technology varied from 25.4 to $33.3 \mathrm{q} /$ ha with a mean yield of $28.4 \mathrm{q} /$ ha. The productivity under different activity i.e. irrigation only at CRI stage, irrigation at CRI and flowering stage and sowing of crop with help of seed drill varied from 24.6 to 32.8 , 28.6 to 36.5 , and 23.0 to $30.5 \mathrm{q} / \mathrm{ha}$, respectively with mean vales of $27.0,31.3$ and $27.0 \mathrm{q} /$ ha against the

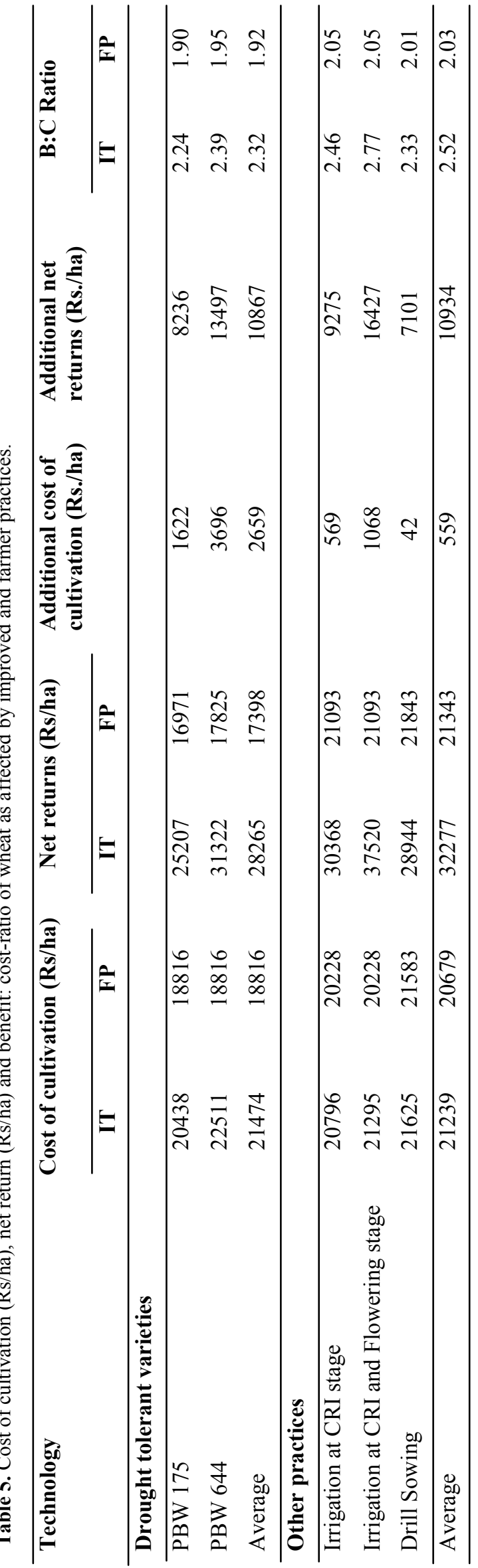


farmer practices with yield range from 21.7 to $22.7 \mathrm{~kg} /$ ha and mean of $22.0 \mathrm{q} /$ ha (Table 5 ). The irrigation only at CRI stage, irrigation at CRI and flowering stage and sowing with help of seed drill gave 5.3, 9.5 and 4.3q/ ha additional yield which was 24.3, 43.9 and 19.0 per cent higher over the farmer's practices.

The variation in the productivity was caused by delay in sowing in some of the farmer's fields due to delayed onset of monsoon, prolonged dry spell during the growth period and variation in soil fertility in the farmer fields. The productivity enhancement of different crops through front line demonstration on improved technologies has been reported by Tiwari et al. (2003), Mishra et al. (2009), Dhaka et al. (2010), Sreelakshmi et al. (2012), Tiwari et al. (2014) and Joshi et al. (2014) and the FLDs conducted in the present study also resulted in yield enhancement which is in line with the results reported by these workers. The results indicated that performance of improved varieties was better than the local cultivars and farmers were motivated by HYVs and improved technologies demonstrated in the FLDs which will result in adoption of these improved technologies.

Economics: The economic analysis of improved technologies over traditional farmer's practices was calculated depending on the prevailing market prices of inputs and outputs (Table 5). It was found that cost of production of wheat under improved technologies varied from Rs. 18816 to Rs. 21,474, Rs. 20,228 to Rs. 21,295 and Rs. 21,583 to Rs. 21,625 per ha with average value of 28,265, 37,520 and 28,944 for rainfed varieties and Supplementary irrigation at CRI and Flowering stage sowing of wheat with the help of seed drill, respectively in comparison to average cost of production of Rs. 17,398, 21,093\&21,843 for local practices. The additional cost incurred in the improved technologies was mainly due to more costs involved in the cost of improved seed and cultural practices. FLDs recorded higher mean net returns i.e. Rs. 10,867 and 10,934 per ha with higher $\mathrm{B}: \mathrm{C}$ ratio of 1.92 and 2.03 for rainfed varieties and other improved technologies (supplementary irrigation and use of seed drill), respectively. Gurumukhi and Mishra (2003), Sawardekar et al. (2003), Hiremath and Nagaraju (2009), Sreelakshmi et al. (2012) and Joshi et al. (2014) also reported higher net returns and B:C ratio in the FLDs on improved technologies compared to the farmers' practices and are at par with results of the present study which also resulted in higher net returns through FLDs on improved technologies. Thus results from the present study clearly brought out the potential of improved production technologies in enhancing wheat production and economic gains in rainfed farming situations.

Increase in knowledge: The knowledge level of the farmers on various aspects of improved production technologies in wheat increased by 29.50 after implementation of frontline demonstrations (Table 6).
Table 6. Comparison between knowledge levels of the respondent farmers about improved management practices of wheat $(n=100)$.

\begin{tabular}{cccc}
\hline \multicolumn{3}{c}{ Mean score } & $\begin{array}{c}\text { Calculated ' } t \text { ' } \\
\text { value }\end{array}$ \\
$\begin{array}{c}\text { Before } \\
\text { FLD }\end{array}$ & $\begin{array}{c}\text { After } \\
\text { FLD }\end{array}$ & $\begin{array}{c}\text { Mean } \\
\text { difference }\end{array}$ & \\
\hline 39.0 & 68.5 & 29.50 & $8.86^{*}$ \\
\hline
\end{tabular}

Significant at $5 \%$ probability level

As the computed value of 't-test' (8.86) was statistically significant at $5 \%$ probability level. The results of the present study are at par with the findings of Narayanaswamy and Eshwarappa (1998) on pulses crops, Singh and Sharma (2004) on mustard crop, Singh et al. (2007) on different crops like soyabean, pigeon pea, black gram and Dhaka et al. (2010) on maize crop who also reported significant increase in the knowledge of the farmers towards improved crop management practices after conducting the FLDs. In other words there was significant increase in knowledge level of the farmers due to frontline demonstration. This shows positive impact of frontline demonstration on knowledge of the farmers that have resulted in higher adoption of improved farm practices.

\section{Conclusion}

The frontline demonstrations conducted on wheat at the farmers' fields revealed that the adoption of improved production technologies significantly increased the yield as well as yield attributing traits of the crop and also the net returns to the farmers. However, the yield level under FLD was better than the local varieties and performance of these varieties could be further improved by adopting recommended production technologies. Hence, it can be observed that increased yield was due to adoption of high yielding varieties and conducting front line demonstration of proven technologies. So, there is need to disseminate the improved technologies among the farmers with effective extension methods like training and demonstrations. The farmers should be encouraged to adopt the recommended package of practices for the crop for higher returns. From the above research findings it can be also concluded that the maximum number of the respondents had medium level of knowledge and extent of adoption regarding recommended wheat production technology. The study reported lack of suitable high yielding rainfed wheat varieties as major constraint by the beneficiaries and is ranked first followed by damage by wild and stray animals, uncertainty of rains, low technical knowledge and yellow rust disease of wheat, respectively.

\section{ACKNOWLEDGEMENTS}

We sincerely thank all the farmers on whose fields' frontline demonstration were conducted. The financial assistance and technical support provided by All India Coordinated Research Project for Dryland Agriculture, 
National Initiative for Climate Resilient Agriculture (NICRA) and Directorate of Research, Punjab Agricultural University, Ludhiana is duly acknowledged. The views expressed in this paper are those of individual scientists and do not necessarily reflect the views of the donor or the authors' institution.

\section{REFERENCES}

Anonymous (2013). Statistical Abstracts of Punjab. http:// www.esopb.gov.in/static/PDF/Statistical-Abstract2013.pdf

Dhaka, B.L., Meena, B.S. and Suwalka, R.L. (2010). Popularization of improved maize production technology through frontline demonstrations in south-eastern Rajasthan. J. Agril. Sci. 1(1):39-42.

Dhruw, K.S., Sengar, R.S. and Yadav, K.N. (2012). Level of knowledge and adoption about recommended maize production technology. Agril. Update 7(3\&4):311-315.

FAO. 2013. FAO Agricultural Production Statistics, http:// faostat3.fao.org/ as accessed on 17 April 2015.

Gurumukhi, D.R. and Mishra, S. (2003). Sorghum front line demonstration - A success story. Agril. Ext. Rev., 15 (4):22-23.

Hiremath, S.M. and Nagaraju, M.V. (2009). Evaluation of front line demonstration trials on onion in Haveri district of Karnataka. Karnataka J. Agril. Sci. 22 (5):1092-1093.

Joshi, A. K., Mishra, B., Chatrath, R., Ortiz Ferrara, G. and Singh, R. P. (2007). Wheat improvement in India: Present status, emerging challenges and future prospects. Euphytica., 157(3): 457-64.

Joshi, N. S., Bariya, M. K. and Kunjadia, B. B. (2014). Yield gap analysis through front line demonstrations in wheat crop. International J. Scientific Res. Pub., 4(9): 1-3.

Katare Subhash, Pandey, S. K. and Mohd. Mustafa (2011). Yield gap analysis of rapeseed-mustard through front line demonstration. Agril. Update, 6: 5-7.

Meena B. L., Meena, R. P., Meena, R. R. and Bhim Singh (2014). Popularization of improved maize (Zea mays L.) production technology through frontline demonstrations in semi arid zone IVA of Rajasthan. J. Appl. Nat. Sci. 6 (2): 763-769.

Mishra, D.K., Paliwal, D.K., Tailor, R.S. and Deshwal, A.K. (2009). Impact of frontline demonstrations on yield enhancement of potato. Indian Res. J. Ext. Edu. 9 (3):26-28.
Mitra, Biplab and Samajdar, T. (2010). Yield gap analysis of rapeseed-mustard through front line demonstration. Agril. Ext. Rev. (April-June): 16-17.

Nagarajan, S. (2005). Can India produce enough wheat even by 2020? Current Sci. 89: 1467-71.

Narayanaswamy, C. and Eshwarappa, G. (1998). Impact of front line demonstrations.Indian J. Ext. Edu., 34 (1\&2):14-15.

Ranawat, Y., Ram, H., Sisodiya, S.S. and Punjabi, N.K. (2011). Adoption of improved maize cultivation practices by trained and untrained farmers of KVK, Udaipur. Rajasthan J. Ext. Edu., 19:144-147.

Samui, S.K., Maitra, S., Roy, D.K., Mondal, A.K. and Saha, D. (2000). Evaluation of front line demonstration on groundnut (Arachis hypogea L.) in Sundarbans. J. Indian Soc. Coastal Agril. Res., 18 (2):180-183.

Sawardekar, S.V., Dhane, S.S. and Jadhav, B.B. (2003). Front-line demonstration performance of salt-tolerant rice varieties in coastal saline soils. IRRN 28 (1):73-74.

Singh, D.K., Gautam, U. S. and Singh, R. K. (2007). Study on yield gap and level of demonstrated crop production technology in Sagar District. Indian J. Ext. Edu., 7 (2\&3):94-95.

Singh, N. and Sharma, F. L. (2004). Impact of front line demonstration on gain in knowledge about mustard production technology among farmers. 2nd National Extension Education Congress, May 22-24, 2004. Society of Extension Education, Agra \& MPUAT, Udaipur: 56.

Singh, V., Singh, R. P., and Pawar, K. S. (1995). Response of wheat (Triticum aestivum) to seed rate and date of sowing. Indian J. Agron., 40(4): 697-99.

Sreelakshmi, C.H., Sameer Kumar, C.V. and Shivani, D. (2012). Productivity enhancement of pigeon pea (Cajanuscajan L.) through improved production technology. Madras Agril. J., 99 (4-6):248-250.

Tiwari, B. K., Aashutosh Sharma, Sahare, K. V., Tripathi, P. N. and Singh, R. R. (2014). Yield gap analysis of wheat (Triticum aestivum) through front line demonstration under limited irrigation conditions. Plant Archives 14 (1): 495-498.

Tiwari, R.B., Singh, V., and Parihar, P. (2003). Role of front line demonstration in transfer of gram production technology. Maharastra J. Ext. Edu. 22 (1): 19. 